\title{
Terroir products: a movable heritage feast?
}

\author{
Harry G. West ${ }^{1}$ (D)
}

Received: 6 July 2020 / Accepted: 29 June 2021 /Published online: 6 August 2021

(c) The Author(s) 2021

\begin{abstract}
This article seeks to de-naturalise the idea of terroir by questioning the assumption that relations between product, people and place are static and durable. It asks what perspectives might be gained by focusing on instances of movement, fluidity, and instability of these three elements and of relationships between them. Whereas terroir contests the idea that anything can be made anywhere by asserting that place and context matter, and whereas anthropologists of space and place critique the essentialisation and naturalisation of place by arguing that, in the context of a globalised world, movement matters, I argue that movement is in fact a crucial element of people's very engagement with place in many productive traditions.
\end{abstract}

Keywords Terroir $\cdot$ Place $\cdot$ Movement $\cdot$ Heritage $\cdot$ Cheese

\section{Introduction}

One of the most celebrated motifs of the heritage foods movement is the French language term, terroir. Those who embrace the term generally suggest that products made by traditional methods express the environmental characteristics of the places in which they are made. They may also suggest that these products reflect the local knowledge and broader cultures of those who make them. Product, people, placethis is the terroir triad, and the concept asserts a profound and enduring relationship between these elements.

In a world where middle-class supermarket shoppers' needs are met "just-in-time" by global supply chains, in which multinational restaurant chains boast, for example, that their chicken nuggets are exactly the same no matter their source or where they are eaten, and in which transnational ag-biotech firms push the same geneticallymodified staple crop seeds on farmers around the world, the terroir idea reasserts that foods are products of particular people in particular places, and that the best foodsin terms of taste, of livelihood provision, or of environmental sustainability-are ones

Harry G. West

h.g.west@exeter.ac.uk

1 Centre for Rural Policy Research, University of Exeter, Exeter, Devon, UK 
that accentuate these linkages rather than diminishing them. By suggesting that we recognise and celebrate food as embedded in deeply historical and profoundly ecological contexts, the terroir perspective resonates with a recent turn in the social sciences toward consideration of the "more-than-human" world in which we live-one defined by bio-diverse ecological niches comprising animals, plants and microbes adapted to distinctive places, and by our dependence upon complex natural processes and relationships that shape us as much as we shape them (Whatmore, 2006; Bennett, 2007; Tsing, 2012; West, 2013b, p. 336; Sarmiento, 2017; Beacham, 2018; Elton, 2019).

The terroir idea is, however, in tension with other contemporary emphases in the social sciences-ones suggesting that globalisation requires us to move beyond static conceptions of human "cultures" as clearly demarcated groups of people, in geographically discrete places, whose practices manifest deep historical continuity. In this article, I focus on how movement-whether of people, of products or even of food-making techniques and ideas-challenges the terroir concept.

Following examination of how the terroir idea has historically linked products and people to particular places, and how this link is called into question in a world shaped by globalisation and movement, I use examples drawn from ethnographic fieldwork with cheesemakers to illustrate the implications of movement for conceptions of terroir. ${ }^{1}$ I begin by showing how movement has in fact long been a part of the environments in which terroir traditions have historically developed and been sustained. I then show how such traditions, and their connections to place, have often been infused by hierarchical relationships between actors on shifting landscapes. The next section contrasts expansive movements by powerful actors such as church and state with the movements of marginalised actors making spaces and productive traditions their own. Subsequent examples show how histories connecting products, people and places may be complicated and "imperfect", but the effectiveness of narratives about these linkages ultimately depends upon the perspectives and interests of tellers and their audiences. This leads to consideration of cases that reveal terroir as an idea with different meanings to different people-itself a product reflecting the natural and social environments into which it has expanded and in which it is (re)produced. I conclude that, if terroir is to have a place in the future food landscape, it must allow for more fluid, more complex relationships between people, product and place-in other words, terroir products must come to be seen as a movable feast.

\footnotetext{
1 Since 2003, I have conducted fieldwork with more than 200 cheesemakers and dozens of cheesemongers in 30 different regions in 13 countries. I thank those I worked with for speaking with me and allowing me to tell their stories and share their perspectives. Research was funded by the British Academy (LRG 45,537). I had no financial interest in, nor derived any financial benefit from, this research. Fieldwork referred to in this article was facilitated by Nuno Domingos, Metin Kap, Ihsan Karayazi, Aylin Öney Tan, Iris Polyzou, José Manuel Sobral, Ewa Spohn, Tangör Tan and Yiorgo "George" Vlahos. I therefore speak of research that "we" conducted, although I am the sole author of this article. Comments on drafts were generously provided by Geoffrey Hughes, David Inglis, Nafsika Papacharalampous and Paul Young, members of the NKUMI group including Nora Faltmann, Lizzie Hull, Jakob Klein, Anne Murcott, Johan Pottier, James Staples, Chenjia Xu and Sami Zubaida, and two anonymous reviewers.
} 


\section{Place matters, but so does movement}

In Tasting French Terroir: The History of an Idea, Thomas Parker tells us: "Terroir evolved from a way of thinking about land that dates to antiquity, and derives from the Latin territorium, signifying the land around a town, that is, a domain, district or territory" (Parker, 2015, p. 5). Contemporary usage in the realm of food refers specifically to how the environmental characteristics of particular lands/territories shape the products made within them. The term first gained currency in reference to wine. As I have explained elsewhere: "The terroir concept suggests... that in wine making, the composition of the soil, seasonal patterns of rainfall and sunshine, the slope and orientation toward the sun of vineyard land and the variety of grapes chosen for cultivation within this environment all profoundly shape a wine, and further, that each region combines these elements in distinctive ways, giving rise to distinctive wines" (West, 2013a, p. 211; see also Wilson, 1998; Guy, 2003, p. 41).

So important is the natural environment to the idea of terroir that, as wine writer and consultant Roger Bohmrich has reported, "some vignerons will staunchly maintain that they are merely the stewards of nature and 'let the wine make itself'" (Bohmrich, 1996, p. 40). People, however, are far more crucial to terroir than this would suggest. According to Parker, for centuries, French conceptions of terroir have suggested that a territory shapes not only the produce of the land, i.e., agriculture, but also the land's producers, i.e., human culturefrom language and literature, to behavioural traits and identities, ways of thinking and, even, individual physiologies (Parker, 2015). Geographers Thomas J Bassett, Chantal Blanc-Pamard and Jean Boutrais have written: "In everyday usage, terroir designates a cultivated area but also a cultural landscape with which the inhabitants maintain historical and affective ties"-even if French intellectual history betrays ambivalence about the social influence of terroir in the form of "a rift between those who idealised rural values and those who favoured progress and change" (Bassett et al., 2007, p. 104).

In any case, just as the terroir idea suggests that a territory shapes people, so too does it suggest that people shape a territory and its products. Indeed, for many, the relevant "environment" for the making of produits de terroir (terroir products) includes people, the knowledge they bear of how best to work within their broader ecology to translate its characteristics into the products they make and the cultural institutions that allow them to sustain and reproduce local knowledge and traditional practices over time.

For example, geographer Warren Moran has warned against "separat[ing] the natural and human components of an agrarian system... when hypothesising the origins of the prestigious winemaking regions of France", instead asking: "By what methods have people in this locality harnessed their natural environment to make fines wines?" (Moran, 1993, p. 705). Geographer Daniel W. Gade has suggested that "skills or practices passed on from one generation to the next" are as essential to the terroir idea as "soil, bedrock, landforms, climate (both macro and micro) and exposure" (Gade, 2004, p. 849). By describing these as "collective 
skills" and "collective practices", Laurence Bérard and Philippe Marchenay have called attention to the social dimensions of these essential elements of terroir (Bérard \& Marchenay, 2008, pp. 10-11, emphasis added), while Amy Trubek, Kolleen Guy and Sarah Bowen have highlighted the importance to terroir of "shared social meanings and practices" (Trubek et al., 2010, pp. 140, emphasis added). This broadening of conceptions of relevant context to include human elements is summed up by historian Tamara Whited, who defines terroir as "a complex and malleable product of the interactions over time between biophysical and anthropogenic factors" (Whited, 2018, p. 826).

Ultimately, the terroir idea leads to conclusions that terroir products are distinctive. Guy tells us, in her history of Champagne, that some argue "[t]he precise conditions of each terroir cannot be duplicated and, by extension, neither can the wines that each produces" (Guy, 2003, p. 41). The same argument has been applied to other foodstuffs, including cheese. Anthropologist Heather Paxson has, for example, written of cheesemakers for whom "physical characteristics of a place... leave an indelible mark on a cheese", making it "so special it [cannot] be replicated elsewhere" (Paxson, 2010a, p. 445). Such ideas have given foundation to claims that rights to make terroir products should be exclusively reserved to those producing by traditionally prescribed methods within an officially delineated territory. Historically, such claims have taken the form of what have variously been called controlled or protected "appellations of origin", "denominations of origin" or "geographical indications" (West, 2013a). In the words of sociologist Sarah Bowen: "As a legal concept, [Denominations of Origin]... are based on the belief that the environmental and cultural characteristics of particular places - their terroir-are translated into the tastes of the foods and drinks produced there and, moreover, that they deserve to be protected" (Bowen, 2015, p. 7). Trubek, Guy and Bowen have described AOCs (Appellations d'Origine Contrôlée) as "certify[ing] and protect[ing] the collective patrimony" (Trubek et al., 2010, p. 142), while Bérard and Marchenay have suggested that AOCs "protect products and production processes that collectively belong to those historical groups and their descendants who developed them and are, therefore, their 'natural' owners" (Bérard \& Marchenay, 1996, p. 240). Anthropologist Cristina Grasseni has written of Italian cheesemakers for whom PDOs (protected designations of origin) were seen as a means of asserting "sovereignty" over a tradition that their forebears had invented, and that they now "reinvented" (in more familiar terms, "reproduced") (Grasseni, 2017, pp. 30-35).

Of course, appellations or indications of origin are meant to protect the bearers of a particular tradition, named after a particular place, from "free-riders" or fraudsters who would use their name and benefit from their good reputation without necessarily adhering to traditional methods, which include producing within a delineated place (West, 2013a, pp. 210-212). As Elizabeth Barham has written: "Labels of origin... hold the potential of re-linking production to the social, cultural and environmental aspects of particular places, further distinguishing them from anonymous mass produced goods, and opening the possibility of increased responsibility to place" (Barham, 2003, p. 129). As Bérard and Marchenay conceive it, this appeals to consumers unsettled by the proliferation of what anthropologist Marc Augé has 
called "non-lieux" (Augé, 1992)—non-places, or no-wheres, spawned by global consumer capitalism (Bérard \& Marchenay, 1996, pp. 234-235).

Barham has also asserted, however, that the terroir idea "relates to a time" not only "when change occurred at a slower pace" but also one "of much less spatial mobility" (Barham, 2003, p. 131). Indeed, the terroir idea is a product of the very places and times in which it emerged and has been reproduced. Terroir made a particular kind of sense, for example, in pre-modern France, where the concept of the nation was scarcely palpable to most rural residents (except in the form of taxes). Graham Robb recounts how a mid-eighteenth century cartographer visited Le Gerbier de Jonc, whose summit afforded a view of one thirteenth of the land mass of France "comprising several small regions whose inhabitants barely knew of each other's existence" and who spoke an array of mutually unintelligible languages (Robb, 2007, pp. 3-4). At that time, people truly had their place in discrete territories. In late-nineteenth and early-twentieth century France, state-led modernisation in the form of national roadways, industrial development, the regularisation of locallevel political institutions, military conscription, a standardised French language and a unified curriculum ironically contributed to the celebration of terroir precisely when regional cultural distinctiveness was perceived to be disappearing-a story told in the classic work of historian Eugen Weber entitled Peasants into Frenchmen (Weber, 1976), tellingly translated into French as La Fin des Terroirs. Of course, regional cultural variations and identities did not completely die out with modernisation. Nor did the trope of terroir's imminent disappearance, which remains salient today, even as it looks to the past. Anthropologist Marion Demossier has associated contemporary articulations of terroir with a "yearning for a return to the countryside", a "reinvention of a rural and peasant identity" and "a desire for landscape appropriation and a life in communities where togetherness, personal recognition and collective participation are easily combined"-in other words, nostalgia for a past conceived from within late-twentieth century socio-economic developments (Demossier, 2000, p. 150).

While it may be true that the terroir idea has served as a means by which people have pushed back against the forces and effects of modernisation and, specifically of late, globalisation, others social scientists have, however, suggested that these very forces and effects should lead us to see celebrations of timeless linkages between things, people and places as atavistic, and to challenge them conceptually. Anthropologists Akhil Gupta and James Ferguson have argued that contemporary global realities have given rise to social subjectivities that belie the notion of "cultures" as spatially bounded entities-e.g., the idea that "France is where the French live, America is where the Americans live, and so on." As "familiar lines between 'here' and 'there'... become blurred", they write, " "cultures' and 'peoples,' however persistent they may be, cease to be plausibly identifiable as spots on the map" (Gupta \& Ferguson, 1992, pp. 10, 12). They quote James Clifford (Clifford, 1988, p. 275), who asks what it means in such a world "to speak... of a "native land"”? (Gupta \& Ferguson, 1992, p. 9). They respond to this rhetorical question with the assertion that "associations of place, people and culture" are not "given natural facts", but instead complex, contingent and processual, and that they must be studied by social scientists precisely as such 
(Gupta \& Ferguson, 1997, pp. 4-6). Like commentators on terroir, Gupta and Ferguson concede that the embrace of place may be a response to the realities of deterritorialisation and displacement. They write: "[A]s actual places and localities become ever more blurred and indeterminate, ideas of culturally and ethnically distinct places become perhaps even more salient" (Gupta \& Ferguson, 1992, p. 10). But they ultimately assert that bounded cultures must be seen as "literary fiction[s]" (Gupta \& Ferguson, 1997, p. 3) and that, like their colleague, anthropologist Lisa Malkki, we must challenge "a nostalgia for origins" in which "the rootedness of peoples and cultures in 'their own' territories is... the takenfor-granted "natural order of things"” (Gupta \& Ferguson, 1997, pp. 6-7).

Such an approach does not discount the importance of place in our world today. In a recent overview of the anthropology of space and place, Pauline McKenzie Aucoin tells us this growing field of study "recognises that landscape, space and place represent important sites for cultural meaning, social and political memory and public discourse" (Aucoin, 2017, p. 407). But as Gupta and Ferguson called for some time ago, this study must permit for-even focus on- " $[\mathrm{t}] \mathrm{he}$ ability of people to confound the established spatial orders, either through physical movement or through their own conceptual and political acts of re-imagination" (Gupta \& Ferguson, 1992, p. 17), rather than merely (to use terroir terminology) expressing them. Anthropologist Setha Low has echoed this, advocating recognition that "new forms of spatiality centre on the individual and his/her movement... throughout the world" as well as the idea (which she attributes to anthropologist Arjun Appadurai (Appadurai, 1996)), that associated conceptions and claims of sovereignty are "limited and translocal" (Low, 2009, p. 33).

This has implications, as well, for how we view claims of ownership over forms of cultural heritage purportedly tied to place. By recognising the importance of movement - both of people and of things - in our world today, we not only loosen the bonds tying people and products to place, but also, potentially, those tying people and products to one another. In this vein, an essay by anthropologist Michael Brown, entitled "Heritage as Property", raises significant questions. Upon close historical examination, he tells us, the Navaho tradition of rug weaving has its origins in several other places and cultural traditions, including: Spanish sheep breeding; the weaving knowledge of Pueblo Indians forced into exile among the Navaho; and designs and colour schemes provided by Anglo-American traders. Brown consequently concludes, "at a fundamental level Navahos cannot claim absolute ownership of the Navaho rug as an art form"; he affirms that "Navaho weavers are admired for their skilled craftsmanship and impeccable sense of design", but he asserts, somewhat controversially, that "the rugs for which they are justly famous are a medium that emerged from the Spanish colonial period"-an art form that "evolved in collaboration with other Indian peoples and Hispanic and Anglo-American settlers as part of their shared historical encounter" (Brown, 2004, p. 59). Brown's work leads him to ask, Who Owns Native Culture? (Brown, 2003). But even as he challenges the erasure of cultural influences upon the Navaho, he risks facilitation of the (re)appropriation of Navaho identity by cultural others and the dispossession of their heritage - a quandary that serves to remind us that the politics of heritage is profoundly shaped by complex fields of power. 
Building on the works cited above, I seek in this article to de-naturalise the terroir idea by questioning the assumption that relations between product, people and place are static and durable. To this end, I ask what perspectives might be gained by focusing on instances of movement, fluidity and instability of these three elements and of relationships between them. Whereas terroir contests the idea that anything can be made anywhere by asserting that place and context matter, and whereas anthropologists of space and place critique the essentialisation and naturalisation of place by arguing that, in the context of a globalised world, movement matters, I argue that movement is in fact a crucial element of people's very engagement with place in many productive traditions. Complementing and complicating the terroir picture with the examination of stories that play out on translocal, transnational and even global scales, I look at how the movement of people, products and ideas confounds socio-economic regimes animated by the terroir idea. While the contemporary embrace of terroir, and associated claims to sovereignty over terroir traditions, may be seen as a response to the placelessness of industrial foodways, I look at those who treat the idea that Gruyère, for example, necessarily lives in Gruyère-that it can be seen as a point on the map, and that it has one "native land"-as discursive constructions. In so doing, I ask, echoing Brown, who owns terroir traditions? Whereas Brown suggests the need to trace such cultural elements back, to origins, for a more complex and inclusive view of ownership, however, I suggest the need to trace the peregrinations of terroir traditions forward, to new destinations, for in such cases, arrivals can be as significant as origins to heritage claims. In so doing, I also pay close attention to how the terroir triad of product, people and place has historically been shaped by power, and how recognition of the importance of movement to people's engagement with place may be seen by some as a threat to heritage claims while simultaneously seen by others as essential to their articulation.

\section{Transhumance and resettlement: from the expansion of terroir to the transplantation of terroir products}

In his classic work on the Mediterranean, historian Fernand Braudel looks in detail at the pastoral practice of transhumance-the seasonal movement of livestock, generally from a place in close proximity to a permanent residence to a place of temporary settlement, e.g., from lowland villages to remote highland pastures, in order to optimise good forage (Braudel, 2000 [1949], pp. 60-76). For people practising transhumance, terroir must surely encompass the entire range of such movements. However, Braudel's analysis complicates matters. While he differentiates transhumance from nomadism - in which all settlements are temporary-he tells us these institutions shade into one another when viewed through the lens of the longue durée. And there is another form of movement we might add to the picture, namely resettlement, from which and into which the practices of transhumance or nomadism may also transform over time. Such was the case with the Wallachians-transhumant pastoralists originating in the Danube River basin region who were Romanised under the Byzantine Empire. They grazed their flocks in the Carpathians, moving to-and-fro as far west as the Polish Tatras. When Byzantium collapsed, their centre of gravity 
shifted westward, and then, when new borders emerged in the aftermath of the Ottoman empire, seasonal movements between nations became difficult (Michałek, 2007). Our ethnographic research reinforced this perspective. Waldemar and Beata Maziejuk (interview, 2010), who made cheese in Tyława, Poland, told us that Wallachains had first come to the region from what is now Romania and Ukraine to graze their flocks in transhumance, but eventually settled permanently. What is more, they told us, the Wallachians brought with them their cheesemaking traditions, which were subsequently embedded in this new locality. In Leśnica, Poland, Kazimierz Furczoń (interview, 2010), who made Oscypek - a cheese celebrated today as Polish heritage - confirmed that local cheesemaking traditions were brought there between the thirteenth and eighteenth centuries by Wallachian shepherds.

Poland was not the only place to which Wallachian migrants brought their cheesemaking traditions. At the Dairy Research Institute and Dairy School in Ioannina (Greece), lecturers Kostas Mantzaris and Emilianos Velivasis (interview, 2011) told us that the Greek cheese Kasseri (recognised today by a PDO) had been brought to Greece by Vlach shepherds-the Greek name for Wallachians. And Vlachs were not the only migrants to carry cheesemaking traditions through Greece. Indeed, there has been continuous movement and counter-movement into the nineteenth, twentieth and even twenty-first centuries of numerous populations-whether other exogenous religious, ethnic, or linguistic communities or indigenous transhumant pastoralists, such as the Sarakatsani. As they have moved, these various populations have carried their cheeses with them-whether in the form of recipes, techniques, flavours or names. According to Andromachi Oikonomou (interview, 2011), who met with us at the Hellenic Folklore Research Centre in the Academy of Athens, they have also subtly adapted their cheeses to new environments and shared them with new neighbours, while also borrowing from those they have encountered along the way. The roster of PDOs for Greek cheeses bears evidence of this. The Greek state recognises multiple PDOs - and these are consequently recognised by the EU because Greece is a member state. However, many of these PDOs-which by definition ought to protect a specific place name-make no reference to a particular place or region within Greece (Petridou, 2012, p. 29). This, we were told by cheesemakers and academics alike, is because the contemporary Greek landscape of cheesemaking is the product of criss-crossing historical migrations of pastoral communities, who carried cheesemaking techniques and names for cheeses with them, sometimes reproducing these together, themselves, and sometimes passing one, the other, or both on to those they encountered. As a consequence, one now finds very similar cheeses scattered across the country bearing different names, as well as disparate cheeses bearing the same name. At Sochos, in Langadas, Central Macedonia, cheesemaker Eleni Prika (interview, 2011) told us that because these entangled traditions rendered inconceivable any attempt to sort out where and to whom cheese names and cheesemaking techniques belonged, and because the Greek state lacked the resources for close certification and regulation, Greek authorities instead defined many PDOs so broadly that anyone using a name anywhere in the country could be included, regardless of variability in production methods or product characteristics.

By contrast, transhumance and resettlement have sometimes brought greater similarity to products over an expanded territory. The practice of using cardoon thistle 
as a coagulant instead of rennet-which is today a distinguishing characteristic of nearly all Portuguese ewes' milk cheeses-was first introduced to cheesemakers in the highland Serra da Estrela by transhumant shepherds from the arid plains of the Alentejo (where cardoon is indigenous) when they expanded their range of transhumance after the Reconquista (West, 2020, p. 111). Tracing further back, knowledge of how to use cardoon was originally brought to the Alentejo by the Romans, whose familiarity with the technique was documented in the first century AD by Columella (Kindstedt, 2012, p. 101).

Whereas Gupta and Ferguson suggest that the geographical fixity of culture has become unsettled within the "pulverised space of postmodernity" (Gupta \& Ferguson, 1992, p. 9), examples such as these show that the cultures of terroir have been characterised by dynamism and movement for much longer (West, 2020). They also illustrate the idea, advanced by anthropologist Keith Basso in his study of landscape and language among the Western Apache, that although culture and place shape one another, the wisdom and memories archived in particular landscapes are absorbed by those who "drink" them in, and are potentially carried on life's journey to other locales where they may inform future practices (Basso, 1996, pp. 55, 76, 85; see also Aucoin, 2017, p. 403)—whether within regions, or across the boundaries of nations and states. And if, as I suggested above, terroir must stretch to encompass the range through which transhumant pastoralists have moved, must it not also be stretched to cover the places where transhumance has transformed into resettlement?

\section{Terroir, relocation and hierarchies of knowledge}

The story of Alentejo cheesemakers illustrates another fundamental point about the implications of the expansion or relocation of terroir traditions. In the modern era, the Alentejo's signature cheese-named after the town of Serpa-was largely made by hired hands on herdades (latifundia estates), until Portuguese industrialisation, urbanisation and the declining competitiveness of Portuguese farming in the 1950s and 1960s led to estate owners abandoning cheesemaking, and to out-of-work cheesemakers setting up their own small dairies in their small residences in town. When a new market niche for artisan foods emerged in the late twentieth century, however, land owners set up new dairies. When we were conducting research in the region, land owners portrayed their estates as the traditional locales for Serpa cheesemaking, while town-based cheesemakers cast themselves as the continuous stewards of Serpa cheesemaking knowledge (West \& Domingos, 2012, pp. 130-136, 140). These conflicting claims, which rent asunder the environmental and social strands of terroir, bore evidence of class tensions rooted in residual social hierarchies that continue to shape the region. While historically powerful land owners saw ex-labourers as absconding with their heritage, newly established entrepreneurs saw themselves as asserting previously silenced claims to heritage.

This should come as no surprise. Gupta and Ferguson remind us that connections to places are often created and sustained by forces that produce disparities and hierarchies (Gupta \& Ferguson, 1992, p. 8) (Gupta \& Ferguson, 1997, p. 2). And commentators have sometimes recognised that the terroir concept may reinforce social 
hierarchies in the places where it is embraced. For example, Guy suggests that the celebration of an abstract and timeless savoir-faire within French terroir discourse has often obscured actual relations of production (what Marx referred to as homo faber being silenced by and subordinated to those who "create value" in a postFordist context through branding and marketing), thereby erasing the heritage claims of the working class (Guy, 2011). Demossier analyses the tensions inherent in such hierarchies, and the forms of dispossession of heritage these entail, in her detailed study of terroir and the AOC for Burgundy wines, wherein she suggests "the wealthiest landowners... dominated the reorganisation of the market", and "by the middle years of the twentieth century, terroir and the AOC legislation that underpinned it had become a powerful ideology supporting the economic and social hierarchy of Burgundian wines, leaving little space for contestation" (Demossier, 2011, pp. 690-691; see also Fourcade, 2012).

Such hierarchies have also shaped AOCs for cheese. For example, King Charles VI's decree in 1411 that the Roquefort name could only be used in the sale of cheeses aged in the caves of Roquefort-sur-Soulzon-later underpinning the first ever AOC (West, 2013a, p. 209)—allowed Roquefort makers to source their milk from a much larger region, setting the proprietors of Roquefort caves atop a hierarchy that reached throughout the region. As the demand for the cheese grew, the syndicate that controlled the AOC decided to permit cheesemakers to source their milk from even further afield, reaching well into the Pyrenees. Julien Lassalle (interview, 2009) - a Béarnais cheesemaker who we visited in Lourdios (France) — told us that because Roquefort makers had such a good market for their cheese, they were able to pay shepherds well for their milk and, consequently, many Béarnais started to sell to them rather than make their own cheeses. However, as Basque cheesemaker Peio Etxeleku (interview, 2009) of the Fromagerie Agour, in Helette (France) reminded us, in time, scientific improvement of the Lacaune breed from which Roquefort was made led to dramatic rises in the productivity of flocks closer to Roquefort, and Roquefort makers no longer needed milk from shepherds further afield. As most Pyrenean shepherds had abandoned cheesemaking, when they lost the market for their milk the region fell into crisis-victims of the opportunistic expansion and contraction of the Roquefort empire. ${ }^{2}$

Terroir traditions may be bound up with hierarchies on even broader historical and geographical scales. For example, the monastic orders of mediaeval Europe served as vectors for the transmission of cheesemaking knowledge along the networks that connected their abbeys. In the Alpine regions, monks learned from local peasants how to make large, durable cheeses that preserved the milk harvested from cattle grazed on rich summer pasture. The crucial technique, that had defined the Luna cheeses of Etruria and Liguria which came to be coveted in ancient Rome, was

\footnotetext{
${ }^{2}$ Béarnais and Basque shepherds ultimately created their own AOC in 1980 for an uncooked, pressedcurd raw ewe's milk cheese that drew inspiration from cheeses historically made by the two groups, and they prohibited the use of milk from Lacaune sheep. As Julien Lassalle (interview, 2009) and Peio Etxeleku (interview, 2009) explained to us, they called the cheese Ossau-Iraty, respectively, after a mountain of symbolic import to the Béarnais and a forest of significance to the Basques. (See also Millet, 2019).
} 
likely pioneered by Celtic cheesemakers living in the region in the pre-Roman era. It entailed cooking the curd to drive out moisture - a process that killed off mesophilic bacteria and left only thermophilic bacteria, giving the cheese a nutty taste (Kindstedt, 2012, pp. 58-60, 105-109, 151-152). The Benedictines and Cistercians who came to own large swaths of land in the Alps in the medieval period embraced this technology, but they also set themselves up as processors of the milk produced by local peasants and as market leaders in the sale of this valuable agricultural commodity. What is more, they conveyed this knowledge to their brethren elsewhere. For example, Benedictines in the Parma region began to make alpine-style cheeses soon after clearing forests and draining marsh land donated to them in the thirteenth century. The warmer, drier ecology differed greatly from the Alps, and local farmers had previously made only small cheeses from the milk of sheep grazed in close proximity to their homes (de Roest, 2000, pp. 20-21), but the Benedictines wished to make larger, more durable cheeses that could be sold into distant, more lucrative markets to generate valuable revenue for the order, so they adopted and adapted their brethren's alpine recipe (Kindstedt, 2012, pp. 155-157). Cooking the curd allowed them to drive out moisture and to make a lower fat cheese that was less susceptible to spoilage despite the poor quality of milk they collected from local peasants before establishing their own herds. To ensure adequate flavour, they developed the technique of combining full fat morning milk with skimmed milk from the previous evening, but the cheese scarcely concealed its alpine origins (Kindstedt, 2012, pp. 155-157). And the strategy worked. According to the author of Parmigiano-Reggiano's official history, Mario Zannoni (interview, 2008), some 30\% of the cost of construction of the San Giovanni Evangelista church in Parma was met by the making of cheese, consolidating the order's symbolic power in the region.

\section{Secular cheese missionaries and post-colonial simulacra}

Religious orders have not been the sole agents of cheese proselytisation. Secular agents of conversion have also historically spread the word of particular cheesemaking traditions. Consider, for example, the story of Graviera on the Greek Island of Crete. Although Graviera is recognised by a PDO as a traditional Greek cheese, we were told by Andreas Protopapadakis (interview, 2011) — who made the cheese in Anopoli, Sfakion-that it had only been made in Crete since the 1940s. Sifis and Manousos Stayrianoudakis (interview, 2011)—who made Graviera in Vamos, Chania—told us that cheesemakers in Crete had learned to make the cheese not from their forebears but rather at a dairy school in the town of Rethymnon, where the technique was taught beginning in the late 1920s. Nikos Gasparakis (interview, 2011), who made Graviera in the cheeseroom on the ground floor of his house in the village of Koumoi on the edge of Rethymno in Crete (Greece) when we visited him, was the son of a shepherd, and went to this school which, he told us, was an offshoot of a larger dairy school (referred to above) in Ioannina in the north of Greece where the best students from Rethymnon ultimately transferred to further their studies. When we later visited Ioannina, we learned from Kostas Mantzaris and Emilianos Velivasis (interview, 2011) that the school had been founded in 1916, and that one of its instructors was an agronomist 
who travelled abroad to learn and repatriate technologies that might aid in the development of farming and food making in Greece. He also spent time in Rethymnon, where he taught students how to make a cheese modelled on the Swiss cheese, Gruyère. ${ }^{3}$ Prior to this, we were told, shepherds on the Island of Crete mostly made a cheese called Soulotyri. Its name, meaning "squeezed cheese", betrayed its simplicity. Made in high mountain shepherds' huts called mitata, the curd was lightly salted, and moisture was driven out only by squeezing the curd in cheesecloth and hanging it to drain. The Stayrianoudakis brothers told us that, because of its high moisture levels, this cheese was unstable and unpredictable, and that it could be aged only for a short time. Graviera presented advantages over Soulotyri, in that it could be aged longer, allowing those who made it to consume this valuable source of protein throughout the year. It was therefore considered by teachers and students alike to be an "improvement" on local cheesemaking technologies, and was widely adopted. What allowed Graviera to be aged longer were methods of production used in the making of Swiss Gruyère. We watched as the Stayrianoudakis brothers cut the curd into small pieces, cooked it for $90 \mathrm{~min}$ at $50{ }^{\circ} \mathrm{C}$ while stirring with a cutting harp, and then elevated the temperature to $52^{\circ}$ while stirring for another $30 \mathrm{~min}$, until the pieces of curd were no bigger than lentils. Once formed, their cheeses were placed in a brine bath with $80 \%$ salt saturation for 10 days before being deposited in the ageing cave. Indeed, the make closely mimicked Gruyère production, from the copper-lined vat in which the cheese was made to the use of an enormous cheesecloth-held by two corners in the cheesemaker's mouth while the other side was manoeuvred under the curd with the aid of a flexible steel band around which it was wrapped - to hoist the curd from the vat and drain it. While the dissemination of Swiss dairying technology might be cast as an act of cultural appropriation, however, it certainly was not seen as such by Swiss instructors who intentionally sought to disseminate their expertise-a project long supported by the Swiss nation as a form of international projection of Swiss influence. On the other hand, even as the technology of Graviera production originated in Switzerland, Mantzaris and Velivasis asserted that cheesemakers in Greece had adapted this technology to make a cheese that was, in the end, Greek - a claim grounded in small details, like the Stayrianoudakis brothers' use of locally available olive wood, which burned slowly and steadily, to heat the vat.

Gruyère has also been reinvented as local tradition in the northeastern Turkish province of Kars. The complex story of the cheese there called Gravyer illustrates not only how cheesemaking traditions may spatially expand through the agency of nations or states, but also how these traditions may be appropriated by actors on the margins of these geopolitical forces. The story was recounted to us by Ilhan Koçulu (interview, 2011), whom we visited in the village of Boğatepe-where snow drifts completely cover houses in the winter, but pastures are lush in the brief summer time. Koçulu explained that the province of Kars was an historical hinterland (or, perhaps more accurately, interland) over which control has shifted between Armenia, Georgia, the Ottomon Empire, Russia and Turkey. In 1877, Kars- then part of the Ottomon Empire-was invaded by Russia, and in the Treaty of San Stefano which ended the

\footnotetext{
3 While Gruyère has been granted PDO status in Switzerland, a French version has also been awarded a Protected Geographical Indication (PGI) in France.
} 
Russo-Turkish War in 1878, the Ottomans ceded claims to Russian occupiers. In 1885, a group of "Spiritual Christians" called Molokan-pacifists, who resisted the authority of the Orthodox Church, asserting that the milk given by their cattle was a gift from God, and refusing to give up its consumption during Lent-moved to this Russian frontier, where they escaped close scrutiny by the Church in exchange for serving as a buffer against Ottoman neighbours. The Molokan did not make cheese, but the milk of their cattle, some of which they marketed, attracted people who did. These cheesemakers came from Russia, but they were in fact Swiss. Indeed, from the mid-eighteenth century, considerable numbers of Swiss migrants had been living and making cheese in the Russian-controlled Caucasus Mountains region. The marriages of several Tsars to Germanic wives had encouraged migrants to Russia from German-speaking Europe, meaning there was a demand for Alpine-style cheeses; what is more, successive Tsars had invited German-speaking artisans to come to Russia to contribute to its development - promising exemption from taxation and military service for 50 yearsand Swiss German investors saw the opportunity to make profits in the development of dairying in the Russian Empire. While these Swiss cheesemakers first settled in Georgia, they also moved into Kars after it came under Russian control. By 1892, 280 tonnes of cheese were being shipped per year from Kars to Russia. By 1905, there were 16 Swiss dairies operating in the region, all of which made cheese for export to Russia, even if much of what they made was shipped on to Western Europe.

Following the Russian Revolution in 1917, many Swiss living in Georgia sold their dairies to Terekeme herdsmen - a semi-nomadic Muslim Azeri sub-ethnicity also known as Karapapak, or, the "Black Hats"-from whom they had long been buying their milk. These Terekeme herdsmen now started making cheese themselves. However, their growing wealth put them in conflict with the Bolsheviks, who eventually gave their lands to Armenians, prompting them to take refuge in Kars and the neighbouring region of Ardahan, which were ceded to Turkey by the Soviet Union in 1921. Turkish control of these regions led Swiss cheesemakers there to abandon their dairies, and these newly arrived Terekeme migrants took them over. Ilhan Koçulu's great-grand-father and his four brothers were among them, first taking up residence in Ardahan. They not only cross bred their cattle with local stock, giving rise to a new, local breed, ${ }^{4}$ three of these brothers also married daughters of Swiss cheesemakers, giving rise to a Gravyer cheesemaking lineage that would predominate in the region for decades to come. ${ }^{5}$

\footnotetext{
4 This is just one example of the movement and transformation of livestock that we encountered in our research. While it is glossed here as a component part of a productive tradition, an entire paper might be written exploring the significance of the movement of animals, or indeed other non-human organisms such as starter cultures or mould sprays, to conceptions of terroir.

5 When we visited Ilhan Koçulu in 2011, he was actually rebuilding the family dairy in Boğatepe. The Molokan had left Boğatepe by the 1960s, migrating to destinations around the globe, and the Koçulu family had moved there from Ardahan. But in the late 1970s, political tensions between right- and leftwing parties - the former embraced by elders in the family, and the latter by the youth-had torn the family apart. Following the military coup in 1980, 16 family members of the younger generation were imprisoned (including Ilhan), with two killed by authorities, and cheesemaking in Boğatepe had collapsed. Upon release from prison in 1989, Ilhan had worked for a large cheese factory in western Turkey, but he soon grew disenchanted with the industrial manufacture of cheese-which he considered bad for consumers-and, in 2000, returned to Boğatepe to rebuild his family dairy, prompting several cousins to follow suit. He told us that he now made the cheese his family had traditionally made.
} 
Like Cretan Graviera, Gravyer in Kars resembled Gruyère. In a copper-lined vat, the curd was cut into small pieces and cooked to expel whey. Its makers wrapped the side of the cheesecloth in a band and slipped it beneath the curd before hoisting it and placing it in moulds for pressing. Like Gruyère, Gravyer was made in enormous thin wheels. But even as they recognised its Swiss origins, Koçulu and his family members considered their cheese a local tradition. Cheesemakers at Latifoğlu Süt (interview, 2011) — who had been forced by inspectors to relocate to the town of Kars-told us that only the grasses of Boğatepe were right for making Gravyer.

Gupta and Ferguson write: "In a world of diaspora, trans-national culture flows, and mass movements of populations, old-fashioned attempts to map the globe as a set of culture regions or homelands are bewildered by a dazzling array of postcolonial simulacra, doublings and redoublings..." (Gupta \& Ferguson, 1992, p. 10). Cretean Graviera and Kars Gravyer are examples of such "doublings and redoublings"-both foreign and domestic, both exotic and local. They are the product of both the projection of Germanic Swiss cultural, political and economic power (not to mention Russian or Turkish power in the case of Gravyer) and Cretean, or Molokan/Terekeme evasion of power and its reworking to different ends. They are also emblematic of the complex relationship between, on the one hand, those who proselytise on behalf of scientific knowledge, and on the other hand, converts who appropriate such knowledge and adapt it to their own purposes in their own social, economic and environmental contexts.

\section{Imperfect pasts and compelling historical narratives}

The story of another cheese straddling the divide between Europe and Western Asia not only further illustrates the importance of state power and people's varied strategies to find hospitable spaces within a shifting geopolitical landscape, it also highlights the crucial role of historical narrative for those seeking to reproduce a tradition they consider their own. Kashkaval is made by immersing shredded fresh curd in hot water, stirring and draining it, and then stretching the warm curd before forming and ageing. Stretched curd cheeses by this name are made today in Albania, Bulgaria, Hungary, Israel, Macedonia, Moldova, Romania, Russia and Serbia (Raxhimi, 2016b, p. 1; Harbutt, 2009, p. 260). A virtually identical cheese called Kaşar, or Kasher, is made in southern Albania, Greece and Turkey (Raxhimi, 2016 b, pp. 3-4). But how did this cheese-which people in numerous locales claim as their own - come to be made in so many places?

We first encountered the cheese in East Thrace, Turkey, but cheesemakers there traced it back to Bulgaria. Kaşar maker Adnan Gündoğdu (interview, 2011) told us that the founder of his dairy, Yaman Peynircilik in Malkara, Tekirdağ, had come to Turkey from Bulgaria as a young man (he was now 82) and brought the Kaşar making tradition with him. ${ }^{6}$ Bilal Bilgin (interview, 2011), co-owner of Gelibolu

\footnotetext{
${ }^{6}$ Ergin Özcan (interview, 2011) — who made Kaşar at Ünal Peynircilik, also in Malkara—also told us that the tradition of Kaşar had come from Bulgaria around 50 years ago.
} 
Organic in Eceabat, Çanakkale (Turkey) also told us that stretched curd cheeses such as Kaşar had been brought to Turkey from what is now Bulgaria, but earlier, when the region was under Ottoman control. Among those who suggested Kaşar making had come to Turkey from Bulgaria were those such as Kaşar producer Ergin Özcan (interview, 2011), who associated it with migrants identifying as Pomaks - Slavs who had once been Paulicians but converted to Islam during the period of Ottoman rule. Others, however, associated Kaşar with Jewish migrants. Ilhan Koçulu (interview, 2011)—who had worked for a cheesemaker in the northwest of Turkey during his exile from Boğatepe-told us that Kaşar was brought to the northwest from Plovdivc, Bulgaria in the mid-1920s by a Jewish master cheesemaker named Filibeli Fehmi. Kaşar, Koçulu insisted, had been invented by Jews living in the Balkan regions of the Ottoman empire. Proponents of this theory often pointed to the name, Kaşar, or Kasher. Whereas others suggest this name derived from the Latin word cheese, caseo, they maintained that it came from the Hebrew term, kasher (kosher). In The Treasury of Turkish Cheeses, Suzanne Swan writes: "The word Kaşar, almost certainly had its roots in the Hebrew word, kasher (kosher) meaning fit or proper.... The term kosher would have been applied to the rennet that caused the curds and whey to separate into component parts" (Swan, 2004, pp. 15, 102, emphasis added). Others concur with this, suggesting that the cheese might have been made using a plant-derived rennet substitute to comply with Jewish dietary laws (Raxhimi, 2016b, pp. 3-4; Valsana, 2019).

The association of the cheese with Jewish makers suggests the possibility of even deeper historical roots. One theory, expounded for example by Serbian historian Olga Zirojević, is that it was brought to Istanbul in the late sixteenth century by Sephardic Jews (Raxhimi, 2016c, p. 1; Valsana, 2019). The clue, they suggest, lies in the name, Kashkaval, which would seem to share roots with the Italian stretched curd cheese, Caciocavallo. Caciocavallo can be loosely translated as "horse cheese", a term variously explained as being: a reference to mares' milk, from which it may have been made in the past; a reference to the tax stamp borne by such cheeses made in Naples; a reference to male genitals, which the cheeses resembled; and perhaps most persuasively, a reference to the way these cheeses, traditionally made in paired balls, were tied together and draped over a pole-“à cavallo", as if over a horse's back-to dry (Raxhimi, 2016c, pp. 3-4). Jewish migrants, it may be posited, were the link between Caciocavallo and Kashkaval. When Naples came under Spanish rule in 1442, many Sephardic Jews moved there, and more followed when Spain expelled them from the Iberian Peninsula in 1492. In Naples, they would easily have become acquainted with Caciocavallo. And as many were involved in trade with cities in the Ottoman Empire, with some relocating there in time, they could have carried knowledge of the cheese there. ${ }^{7}$ As the Sephardic diaspora spread throughout the Balkans and beyond, the theory suggests, it served as the vector for proliferating traditions of Kashkaval/Kaşar making (Raxhimi, 2016c, p. 2). According to Swan, the cheese was made by Jews living throughout the Ottoman empire-from Macedonia to Serbia (she tells us that cheese from the Serbian capital, Skopje, was famous). She concludes, quite simply: "The making of Kaşkaval cheese was

\footnotetext{
7 Tan tells us records show that Kaşar was served to the Sultan Mehmed II in 1471 (Tan, 2016, p. 733).
} 
a Jewish tradition" (Swan, 2004, pp. 15, 102 emphasis added). And as the Jewish community in Sofia survived the holocaust, it would make sense that Bulgaria served as a contemporary point of origin for Kaşar making in places like northwest Turkey.

Alternative narratives of the origins of Kaşar/Kashkaval exist. Metin Kap (interview, 2011), who assisted during fieldwork in northwest Turkey, told us that his grandmother referred to un-aged Kaşar curd as "Caucasian cheese", suggesting that it originated in the Caucasus Mountains. Zafer Çelebi (interview, 2011), who made Kaşar at Büyük Zavotlar, in Kars, told us that his ancestors brought Kaşar making with them from Caucasia when they migrated to the region in 1917, following the Russian Revolution. Mahir Kardeş (interview, 2011), who also made Kaşar in Kars, told us that his family had come to the region from Georgia in 1917, bringing the tradition of making Kaşar with them (although he did not claim to know if it "originated" there). He told us that Kaşar meant "matured" in Russian, and that the term was also used to describe a girl with sexual experience. Çelebi told us that he believed the Kaşar tradition had spread from the Kars region to the rest of Turkey. But such accounts do not necessarily contradict the story of Sephardic origins, as the Jewish diaspora in Caucasia may have brought the tradition there in the first place.

Others have suggested that the name traces back to Persian (kashk referring in Farsi to drained soured milk) and to the town of Kavala in present-day Greece where Kashkaval was first made (Valsana, 2019). Still others have asserted that it was first made in the central southern Balkans by Aromanians-a Vlach sub-group whose language reflected Latin influence in the Roman era ( $k a c ̌$ meaning cheese), and for whom the horse reference may have derived from paired cheeses being draped over the necks of horses as they moved in transhumance (Mijačević \& Bulajić, 2004, p. 12). In the World Cheese Book, we are told that Hungarian Kashkaval "has been made since before the Roman Empire", but we are not told for how long it was called by this name (Harbutt, 2009, p. 260).

While it is clear that stretched curd cheeses have a deep history on the Italian peninsula (Columella describes a recipe for "hand-pressed cheese"-similar to Kashkaval—in his De Res Rustica in 68 A.D. (Kindstedt, 2012, p. 102; Raxhimi, 2016a, p. 4; Mijačević \& Bulajić, 2004, p. 12; Valsana, 2019), it is also clear that such cheeses have long been made elsewhere. The name, Caciocavallo, is generally recognised as an awkward construction in Italian (Simon, 1956, p. 84), and the fact that its meaning, and origins, are debated raises the possibility that Caciocavallo is a transliteration of Kashkaval, rather than the other way around, and that the nameperhaps even the recipe-may have been carried in the opposite direction, from east to west (Mijačević \& Bulajić, 2004, p. 12; Androuët, 2002, p. 178; Harbutt, 2003, p. 127), by traders transporting cheese from Constantinople to Amalfi during the era of the maritime republics, or from Albania to Puglia in the Ottoman era (journalist Altin Raxhimi has written that "cacio cavallo" makes its first appearance in literature in Franco Saccetti's Il Trecentonovelle at a time "when the Balkan nations confronted the Ottomans" (Raxhimi, 2016a, p. 4)), or via the networks of the Sephardic diaspora (Valsana, 2019). Regardless of direction, this cheesemaking tradition has moved over considerable distances throughout the centuries, taking root in places well beyond its point of origin and coming to be seen in many such places as local heritage. 
Like so many of the cases examined in this article, the Kashkaval/Kaşar example can be viewed in light of literary scholar Timothy J. Tomasik's critique of "the idealism of a cult of authenticity" often associated with terroir, which suggests that "only things with clear origins have value" (Tomasik, 2001, p. 526). Here, we may take a page from anthropologist Paola Filippucci, whose study of the Argonne-a forested mountain range in northeastern France-tells the story of a place where identity is complicated by a history of destruction and upheaval, most notably during the first world war. So profound is the challenge to a sense of patrimony, she tells us, that locals often point out that "the Argonne does "not even have a cheese"". Quelle horreur! Still, she tells us, these cheeseless people do have a cultural identity, albeit a fluid one shaped by historical events and ruptures. She suggests that the Argonne case challenges conventional notions about heritage which imply that "perfect locations" must have "perfect pasts" (Filippucci, 2004, pp. 72, 83).

Similarly, for many people who do have cheeses, this product need not be grounded in a singular, "perfect place", nor be connected to a singular, "perfect people". This is not to suggest that such products do not express relationships with their environmental and social contexts, merely that the relationships they do express are complicated ones. And sometimes, the force of expression matters as much as, if not more than, the force of the relationship. Take, for example, the case of Korycin, a cheese made in the eponymous town in northeastern Poland. Makers of this moisteven slick-textured-cheese, which is typically consumed within a few weeks of its making, such as Grażyna Szamreto (interview, 2010), surprisingly told us that it, too, could be traced back to a Swiss Alpine cheesemaking tradition. According to their story, a small number of wounded Swiss mercenaries, who had fought along with the Polish army against Swedish invaders during the mid-seventeenth century "Deluge" ("Potop", in Polish), convalesced at a farm outside Korycin in the village of Kumiała. During their stay, they taught their hosts how to make rennet by drying and grinding calves' stomachs, and how to use it to make a "yellow" cheese that was aged for many weeks on rye straw in a cellar (korycin.pl, n.d.). Cheesemakers told us the tradition was passed down through the generations, and the cheese continued to be made on small farmsteads, although those with whom we spoke admitted that today's cheese bore little resemblance to any cheese of Swiss origins. The cheese had been made for centuries by farm families for their own consumption, but the opening of two industrial dairies in the 1970s had led to the near total disappearance of farmstead production while altering the cheese substantially (korycin.pl, n.d.). Small-scale producers "carrying on the tradition" today had emulated industrial manufacturers, using commercial rennet and marketing the cheese fresh. ${ }^{8}$ As the cheese had evolved over time to meet consumer demands, it was in fact difficult to see continuity with a Swiss tradition dating to the seventeenth century. But around 2000, the mayor of Korycin had sought to assist the development of

\footnotetext{
${ }^{8}$ Grażyna Szamreto (interview, 2010) told us that local consumers viewed mould on a cheese's crust as a sign of spoilage, and while fresh cheeses sold well at markets in Warsaw, aged cheeses did not. Indeed, consumers were averse to the flavours produced by lactic fermentation, so Korycin makers renneted fresh milk to form a simple curd without encouraging the acidification that produces more complex flavours.
} 
small-scale entrepreneurship in this remote region, encouraging those still making cheese-as well as those interested in taking up cheesemaking-to develop a narrative that would attract interest from consumers as far away as Warsaw. In a place not known for cheesemaking, local tradition meant little on its own, and so they (re)created a story that accentuated deeper roots, reaching beyond the local to appropriate heritage from a broader historical geography.

Some might consider Korycin's link to Swiss cheesemaking "spurious"- to use a term that anthropologists and folklorists have long suggested creates a dichotomy rather than merely referring to a pre-existing one (Handler \& Linnekin, 1984)—but Polish consumers found the narrative compelling and judged its claims "genuine", quickly leading to the cheese's national renown. Indeed, its distant and faded past was crucial to Korycin's contemporary value. Not all such narratives are compelling to every audience, however. The story of cheeses carried by nineteenth- and twentieth-century European migrants to the "new world" (including North and South America, and Australasia) illustrates this well. Sociologist Elizabeth Barham tells us: "Immigrant business owners of European [origin] were familiar with geographical names from their home countries that were associated with quality products and used them to promote their own products" (Barham, 2003, p. 128)-for example, Cheddar, Gouda and Parmesan. Even when they did not use European place names, these settlers often described their products as being in the "style" of named European ones—e.g., "Gouda-style"—or used a more general reference such as "alpinestyle", or even a novel name albeit in a foreign language evoking connection, such as the Chevre made by Alison Hooper (interview, 2008) of Vermont Butter \& Cheese Company in Websterville (USA). Regardless, "old world" producers have tended to see these productive traditions as "belong[ing] to the region itself"lations abroad as the appropriation of their heritage-and European governments have generally defended this position (Barham, 2003, p. 129). PDO syndicates like Parmigiano-Reggiano have aggressively protected their intellectual property rights through litigation in courts around the world. In this context, Bohmrich suggests, the terroir idea has become a "lightning rod" in a broader "ideological confrontation" (Bohmrich, 1996, pp. 33, 35). He elaborates: "On one side are 'terroirists' with a vested interest who wield the concept as a weapon on the world market to assert that European classics are infinitely superior and will always remain so. On the other side, modernists reject what they perceive as bogus scientific arguments which serve to perpetuate a marketing advantage" (Bohmrich, 1996, p. 44). The divergence of views has taken on geopolitical significance in the context of trade negotiations and disputes, as European nations have cast terroir as an indication of product quality, while those elsewhere have come to see it as a marketing ploy to protect monopolies. In the words of agricultural economist Tim Josling, "[U]sing a [geographical indication] as a proxy for information about consumer attributes of a good may have sound economic as well as social justification"; but, on the other hand, "[i]f a type of product traditionally associated with a geographical region can be successfully produced in regions other than that which gave it its name, then any restriction on the competitive new product is likely to be resisted" (Josling, 2006, pp. 338, 340). And it is not just producers and trade negotiators who look upon terroir claims with suspicion. Geneviève Teil writes: "For scientists, who are unable to reduce it to a stable list of 
determining factors, terroir is an unfounded notion, an imaginary social construction and an economic barrier" (Teil, 2012, p. 478; see also Matthews, 2016). In light of such critiques, we might conclude, as Zachary Nowak has rather bluntly, that "[terroir] is nonsense" (Nowak, 2012, p. 92). A more measured conclusion might take its cue from Gade, who writes diplomatically that "assertions made for terroir are negotiable" (Gade, 2004, p. 865). Indeed, the case for terroir is always a story, and its validity lies not only in the linkages it makes between product, people and place, but also in the motives and persuasiveness of its tellers and the interests and dispositions of its various audiences.

\section{Ideological inflexions and heterodox interpretations in new locales: the terroir of terroir}

By now it should be clear that terroir means different things to different people. To begin with, as Basso has reminded us, individuals' experiences of a given place may differ (Basso, 1996, pp. 55, 84). In the contemporary food world, this is true as well of people's conceptions of the relationship between product, people and place. Teil suggests, for example, that "terroir is... distributed across a vast range of interpretations and "ways of doing" " as vintners "perform a score composed by the terroir" (Teil, 2012, pp. 489, 481-482). What is more, their performance is assessed by a vast number of other actors-wholesalers, wine writers, consumers - with a range of individual interpretations of any given product's terroir. And these actors' interpretations are framed by various institutions, from the syndicates administering designations of origin, to the government agencies enforcing food safety regulations, to the marketplace (West, 2013b). In all of this, it is essential to acknowledge that those who embrace the idea of terroir do not-indeed, cannot-recognise and/or celebrate all of its prior meanings, nor do they necessarily embrace all of the implications of particular terroir assertions. Instead, we see what Szilvia Gyimóthy categorises as "dynamism" rather than "conform[ance] to canonised terroir constructions" (Gyimóthy, 2017, p. 1210), as people deploy the terroir idea to celebrate their own understandings of how their practices relate to their particular social and environmental contexts.

It is important also to remember that the terroir idea itself has travelled. Like particular terroir products and/or methods and styles of cheesemaking, the terroir idea has moved through geographical space, whether within Europe, or to the Americas, Australasia and elsewhere. And because of the prominence of the terroir idea in food discourse worldwide, other ideas, for example about the importance of locality or environment, have increasingly come to be expressed in the terroir idiom. Many of the American cheesemakers with whom we worked recognised European claims to place names, and eschewed cultural appropriation, opting to name their own cheeses differently even when they acknowledged the influence of European traditions on their productive processes. Paradoxically, their break with European terroir traditions was often expressed in the language of embracing their own, local terroir, and as such, constituted an affirmation of this concept of foreign origin. What terroir means to people in disparate places is not, however, necessarily the same as what it 
has meant where the concept originated. The meaning of terroir depends, in other words, on its interpreters' various contexts. Paxson has argued: "The taste of place [a euphemism for terroir (Trubek, 2008)] need not come in one flavour.... There is no reason why the term cannot come to signify different sorts of connections between people and places in different contexts" (Paxson, 2010b, para 10). In other words, as I conceive it, because each terroir interpretation has its own context of production, each invocation of the terroir idea has its own terroir. Terroir is itself a produit de terroir.

By way of example, among American cheesemakers, terroir's expression of the natural endowment has often translated into a focus on environmental sustainability. Paxson categorises such concerns among American cheesemakers as an emphasis on the "taste of cultured nature" (Paxson, 2010b, para 12). But according to Paxson, American cheesemakers do also think about the social dimensions of their productive contexts. Rather than conceiving of this in terms of how their practices are embedded in longstanding cultural traditions, however, Paxson suggests that they resist what anthropologist Arjun Appadurai describes as "incarceration" in the space/category of the "native" (Appadurai, 1988 in Paxson, 2010a, p. 447), and instead interpret their relevant social context in more instrumental terms. This takes the form of what Paxson describes as American cheesemakers' interest in the "taste of proximity"-an interpretation of terroir that celebrates socio-economic embeddedness and the potential to contribute to a local economy (Paxson, 2010b, para 8). ${ }^{9}$ Whereas in historical usage in France, the idea of terroir has conveyed ambivalence (Tomasik tells us that it has often lent esteem to things, but cast people as "country-bumpkins" (Tomasik, 2001, pp. 523-524)), its contemporary connotations are more singular within the global market niche for heritage foods, where it has largely been used to create or add value to products. This is why, as Barham suggests, AOCs "can be considered an important tool for rural development" (Barham, 2003, p. 134; see also Delfosse, 2013).

Paxson tells us that, in the USA, terroir is generally scaled down to the level of individual farms (Paxson, 2010b, para 12). Americans consider their own farm or dairy as a terroir unto itself, and often name their cheeses idiosyncratically-after a feature on their land, or a family member, or even a hobby interest or a family petrather than with reference to a larger, place-based tradition that they reproduce and into which they must fit. Whereas American producers often consider the European focus of terroir on strictly delineated spaces and strictly defined historical methods unproductively constraining for those considered "within" and excessively exclusive of those considered "without", European producers often find Americans' bespoke conceptions of terroir absurd and, ultimately, meaningless. Paxson tells us that American cheesemakers' underpinning histories constitute "shallow temporalities".

\footnotetext{
9 Along similar lines, Trubek and Bowen ask, "Can the concept of terroir be translated and adapted by American producers?" Their answer, in the affirmative, suggests that, to be viable in the USA, terroir must focus on the "impetus to "localise production", which has been expressed through the rising success of farmer's markets, Community Supported Agriculture, restaurant promotion of local foods, and the "locavore movement" (Trubek \& Bowen, 2008, p. 28).
} 
But, she explains, American cheesemakers' conceptions are as much an expression of moral values as they are an investment in the creation of economic value (Paxson, 2010a, pp. 445, 447). Their focus on normative dimensions is not entirely unique. Gyimóthy tells us that, within the New Nordic Cuisine movement-which has introduced terroir to northern Europeans, where it previously held little currency"provenance is more ideological than cartographical and ethics and passion are replacing tradition and history as qualifiers" (Gyimóthy, 2017, p. 2010).

One of the best examples that we encountered of what Paxson and Gyimóthy outline was Mother Noëlla Marcellino, who made cheese at the Abbey of Regina Laudis in Bethlehem Connecticut. The story of her cheese-made in the style of the French cheese, St. Nectaire-depends upon long, thin strands connecting her to the past. Her abbey's founder was an American woman named Vera Duss who took her vows in France and sheltered in the Parisian Abbey of Notre Dame de Jouarre during the second world war, during which time she committed herself to founding an abbey back home at war's end (Marcellino, 2003, p. 52). As Benedictines, the nuns at Regina Laudis were committed to providing for themselves, and when Noëlla's first attempts to make cheese disappointed, her prayers for guidance were answered in the form of a woman from the French Auvergne visiting the abbey and teaching her how St. Nectaire was made (Bilger, 2002, p. 154).

While the story of knowledge transmission leading to Noëlla's Bethlehem cheese may have rested on a relatively shallower temporality than many European terroir products' stories, Noëlla focused on other dimensions. The abbey encouraged her and other nuns to augment knowledge of their productive methods through study at university, and so, she undertook a $\mathrm{PhD}$ at the University of Connecticut, writing a thesis on the diverse strains of moulds essential to the ripening of cheeses, for which she conducted field research in France. Her findings - that there were at least 64 strains of one mould, namely, Geotrichum candidum - might support the idea that, underpinning the diversity of cultural traditions of cheesemaking lays a corresponding diversity of micro-organisms (micro-cultures) embedded in distinctive places, each giving rise to cheeses with distinctive characteristics (Marcellino, 2003, pp. 20-21, 67; see also Bilger, 2002, p. 152; Moore, 2003). Such arguments are common in terroir discourse. Burgundy wine makers, for example, have famously taken the idea of the decisive importance of the manifold and variable natural factors of production seriously, suggesting that wines produced on tiny parcels of land differ significantly from those produced on adjacent parcels, yielding some 690 micro-areas (terroirs) (Allaire et al., 2011, p. 6). Such arguments have not only highlighted variability in space but also through time. Because many of the elements that factor into the terroir equation vary over time within a single locale, such as the weather, some cheesemakers with whom we worked - such as David Major (interview, 2008) of Vermont Shepherd, in Putney (USA) - have argued that each day might be thought of as its own, unique terroir. Carried to such logical extremes, the terroir idea becomes so fine-grained as to be unmanageable. On the other hand, pinning the value of a product to the singularity of particular elements in a productive ecology renders claims to distinctiveness vulnerable when evidence suggests that particular factors of production may be present in disparate places. To wit, the distinctiveness of Mother Noëlla's Bethlehem cheese might have been undermined by her unexpected discovery that the 
very same strain of geotrichum candidum that she isolated in a cave where Alphonse Bellonte (interview, 2006) aged his St. Nectaire cheese in the Auvergne occurred naturally in the cellar where she aged her cheese back home in Connecticut. ${ }^{10}$

For Noëlla, however, singularity of product was not the most important objective. In line with Paxson's and Gyimóthy's suggestions, Noëlla emphasised normative dimensions in her interpretation of terroir (Marcellino, 2003, p. 52). For her, terroir was ultimately about deriving sustenance from God's bounty and providing for her (religious) community. And the serendipity of a strain of geotrichum candidum connecting her cellar to an ageing cave in St. Nectaire, whence came her answer to prayer, could be interpreted as divine providence-not to mention divine provenance!

On a broader scale, we may also see within the Greek administration of PDOs the importance of ideological objectives and the imperative of creating or preserving community. In stark contrast with PDO arrangements in other countries-where certification has been awarded only after the presentation by a group of cheesemakers of evidence of the historical distinctiveness and geographical specificity of their productive tradition, and where the cost of regulation has been borne by PDO members-Greek policy, according to cheesemaker Eleni Prika (interview, 2011), has been conflict averse, egalitarian and inclusive, treating PDO certification as a valuable good to which cheesemakers generally have an entitlement, without having to make a case for distinctiveness, pay fees or comply with production protocols. Kostas Mantzaris and Emilianos Velivasis (interview, 2011) told us that, if you made a cheese by a PDO name, you were accepted into the PDO without doing anything else. $^{11}$

\section{Terroir products: a movable feast in a globalising world?}

In his classic text, Ancient Law, the nineteenth century British jurist and historian Henry Sumner Maine distinguished between immovable and movable property (Maine, 1986 [1861] in Rowlands, 2004, p. 207). More recently, some have categorised forms of heritage as immovable and movable — the latter being applied to "any natural or manufactured object of heritage significance" (New South Wales Government, 2016). This raises the question: might we also consider terroir products and their underpinning traditions movable?

\footnotetext{
${ }^{10}$ Within the heritage foods market niche, it has in fact actually mattered little whether a particular terroir is demonstrably unique. Grasseni observes that the fact that two places provide similar factors or conditions for production does not make the products derived from them any less "typical", so long as they are each seen to be embedded in their own locality (Grasseni, 2017, pp. 42-43).

11 The best known Greek PDO cheese is Feta, the name of which makes no reference to place (it simply means "slice", in Italian!), and encompasses a wide array of cheesemaking practices across the country, as cheesemaker Stelios Dampizas told us at Provogal, in Efkarpia, outside of Thessaloniki (Greece) (interview, 2011) (see also Anthopoulou \& Goussios, 2018); despite this, the EU recognised this Greek PDO, allowing Greek producers to (re)capture the EU market for this type of cheese, in part to bring Greece into the fold of nations invested in geographical indications at a time when some non-European countries were challenging the legitimacy of such forms of intellectual property (West, 2013a, p. 225).
} 
An affirmative answer to this question would require that we take seriously Gyimóthy's idea-which echoes geographer Doreen Massey (Massey, 1999)—that terroir "rests on an extroverted ontology of place" (Gyimóthy, 2017, p. 1205). In other words, it would involve expanding the geographical and conceptual dimensions of terroir, loosening the bonds between products/productive traditions, people and specific places, allowing for the movement of people and productive traditions, and seeing terroir - as some producers do-on a scale that is geographically broader and inherently more complex. This means the embrace of an assertion that is ance more limited and more expansive than terroir orthodoxy which maintains that there is a singular and immutable relationship between a product, its producers and the place in which it is made; it means instead seeing a product as being shaped by the natural and social environments in which it is reproduced, even as these are rendered dynamic by the passage of time and movements through space. This would not diminish the fact that place matters in the reproduction of terroir foods, but would mean recognising that, as the nature of place is ever changing in a globalising world, so too must the relationship between terroir products and the places in which they are made. It would mean, quite simply, seeing terroir products as a movable feast. ${ }^{12}$

If the idea of terroir is to remain salient in future, such a change may be essential. Even in Europe, the links between product, people and place are under great strain, after decades of outmigration from many of the rural places historically associated with terroir products. Such demographic transformation, and the attendant decline of a rural consumer base, has led to the slow dissolution of an under-recognised element of the human dimensions of terroir, namely the familiarity and loyalty of local consumers to particular tastes and associated terroir products. Producers must now connect at a distance with those who have left, or with those who potentially replace themdéracinés, nostalgic for disappearing countryside and dying traditions (West, 2014, pp. 78, 82, 84; West, 2019; see also Delfosse, 2011). At the same time, producers struggle to recruit employees to support them in their day-to-day work, not to mention to identify willing heirs to their productive traditions. Notwithstanding the inherent localism/ nationalism of terroir discourse-for example, campaigns in northern Italy to protect local culinary heritage by banning producers of foreign foods, such as kebabs, from tourist-focused town centres (Strzemien, 2009) — heritage foods are increasingly made by immigrants, such as the Moroccan men we saw making Parmigiano-Reggiano for Luciano Catellani (interview, 2008) at the Caseificio Notari, in Reggio Emilia (Italy), or the Sikhs we saw making Graviera for Nikos Gasparakis (interview, 2011) in Crete (Greece). This is scarcely a form of appropriation, as the survival of these cultural traditions depends upon the inclusion of newly arrived bearers of this heritage.

Rescuing terroir from obsolescence therefore means following Gupta and Ferguson when they echo anthropologists such as Eric Wolf (Wolf, 1982) and Edwin Wilmsen (Wilmsen, 1989), calling for us to recognise the deep and complex transnational historical connections that belie the partitioning of the world into the West and the Rest, colonial metropoles and their hinterlands, or modern cosmopolitan spaces and isolated traditional ones-connections animated by complex relations of

\footnotetext{
${ }^{12}$ Of course, this phrase originally refers to religious feasts with no fixed date on the calendar that move in time, but I refer here instead to spatial movement.
} 
power (Gupta \& Ferguson, 1992, p. 16). Produits de terroir may reflect the ecologies, both human and more-than-human, in which they are made, but in today's world, they cannot still be seen as the products of isolated places. Instead, it must be recognised that they are (re)produced in complex places, shaped by complex histories of movement both within and across borders, and by complicated struggles in which traditions are appropriated by some and disseminated by others.

Author contribution Not required for this journal.

Funding This research was funded by The British Academy (LRG 45,537).

Data availability Due to the nature of this research, participants of this study did not agree for their data to be shared publicly, so supporting data is not available.

Code availability Not relevant for this article.

\section{Declarations}

Conflicts of interest The author declares no competing interests.

Open Access This article is licensed under a Creative Commons Attribution 4.0 International License, which permits use, sharing, adaptation, distribution and reproduction in any medium or format, as long as you give appropriate credit to the original author(s) and the source, provide a link to the Creative Commons licence, and indicate if changes were made. The images or other third party material in this article are included in the article's Creative Commons licence, unless indicated otherwise in a credit line to the material. If material is not included in the article's Creative Commons licence and your intended use is not permitted by statutory regulation or exceeds the permitted use, you will need to obtain permission directly from the copyright holder. To view a copy of this licence, visit http://creativecommons.org/licen ses/by/4.0/.

\section{References}

Allaire, G., Casabianca, F., \& Thévenod-Mottet, E. (2011). Geographical origin: A complex feature of agro-food products. In E. Barham \& B. Sylvander (Eds.), Labels of origin for food: Local development, global recognition (pp. 1-12). CAB International.

Androuët, P. (2002). Le dictionnaire des fromages du monde. Le Cherche Midi.

Anthopoulou, T., \& Goussios, D. (2018). Re-embedding Greek Feta in localities: Cooperation of small dairies as a territorial development strategy. In A. Kalfagianni \& S. Skordili (Eds.), Localizing global food: Short food supply chains as responses to agri-food system challenges (pp. 121-138). Routledge.

Appadurai, A. (1988). Putting heirarchy in its place. Cultural Anthropology, 3(1), 36-49. https://doi.org/ 10.1525/can.1988.3.1.02a00040

Appadurai, A. (1996). Modernity at large: Cultural dimensions of globalization. University of Minnesota.

Aucoin, P. M. (2017). Toward an anthropological understanding of space and place. In B. B. Janz (Ed.), Place, space and hermeneutics (pp. 395-412). Springer.

Augé, M. (1992). Les non-lieux. Seuil.

Barham, E. (2003). Translating terroir: The global challenge of French AOC labeling. Journal of Rural Studies, 19(1), 127-138. https://doi.org/10.1016/S0743-0167(02)00052-9

Bassett, T. J., Blanc-Pamard, C., \& Boutrais, J. (2007). Constructing locality: The terroir approach in West Africa. Africa, 77(1), 104-129. https://doi.org/10.3366/afr.2007.77.1.104 
Basso, K. H. (1996). Wisdom sits in places: Notes on a Western Apache landscape. In S. Feld \& K. H. Basso (Eds.), Sense of place (pp. 53-90). School of American Research Press.

Beacham, J. (2018). Organising food differently: Towards a more-than-human ethics of care for the anthropocene. Organization, 25(4), 533-549. https://doi.org/10.1177/1350508418777893

Bennett, J. (2007). Edible Matter. New Left Review, 45(45), 133-145.

Bérard, L., \& Marchenay, P. (1996). Tradition, regulation, and intellectual property: Local agricultural products and foodstuffs in France. In D. Stabinsky \& S. B. Brush (Eds.), Valuing local knowledge: Indigenous people and intellectual property rights (pp. 230-243). Island Press.

Bérard, L., \& Marchenay, P. (2008). From localized products to geographical indications: Awareness and action. Centre National de la Recherche Scientifique.

Bilger, B. (2002). Raw faith: The nun and the cheese underground. The New Yorker, August 19 and 26, pp. $150-157$.

Bohmrich, R. (1996). Terroir: Competing perspectives on the roles of soil, climate and people. Journal of Wine Research, 7(1), 33-46. https://doi.org/10.1080/09571269608718059

Bowen, S. (2015). Divided spirits: Tequila, Mezcal, and the politics of production. University of California Press.

Braudel, F. (2000 [1949]). The Mediterranean and the Mediterranean world in the age of Philip II. London: The Folio Society.

Brown, M. F. (2003). Who owns native culture? Harvard University Press.

Brown, M. F. (2004). Heritage as property. In K. Verdery \& C. Humphrey (Eds.), Property in question: Value transformation in the global economy (pp. 49-68). Berg Publishers.

Clifford, J. (1988). The predicament of culture. Harvard University Press.

de Roest, K. (2000). The production of Parmigiano-Reggiano cheese. Van Gorcum.

Delfosse, C. (2011). La patrimonialisation de produits dit de terroir. Anthropology of Food, 8. https://doi. org/10.4000/aof.6772

Delfosse, C. (2013). Produits de terroir et territoire: Des riches heures du développement rural à la gouvernance métropolitaine. Sud-Ouest Européen: Revue Géographique des Pyrénées et du Sud-Ouest, 35, 17-29. https://doi.org/10.4000/soe.549

Demossier, M. (2000). Culinary heritage and produits de terroir in France: Food for thought. In S. Blowen, M. Demossier, \& J. Picard (Eds.), Recollections of France: Memories, identities and heritage in contemporary France (pp. 141-153). Berghahn.

Demossier, M. (2011). Beyond terroir: Territorial construction, hegemonic discourses, and French wine culture. Journal of the Royal Anthropological Institute, 17, 685-705. https://doi.org/10.1111/j.14679655.2011.01714.x

Elton, S. (2019). Posthumanism invited to dinner. Gastronomica: The Journal of Critical Food Studies, 19(2), 6-15. https://doi.org/10.1525/gfc.2019.19.2.6

Filippucci, P. (2004). A French place without a cheese: Problems with heritage and identity in Northeastern France. Focaal: European Journal of Anthropology, 44, 72-86. https://doi.org/10.3167/09201 2904782311254

Fourcade, M. (2012). The vile and the noble: On the relation between natural and social classifications in the French wine world. The Sociological Quarterly, 53(4), 524-545. https://doi.org/10.1111/j.15338525.2012.01248.x

Gade, D. W. (2004). Tradition, territory, and terroir in French viniculture: Cassis, France, and the appellation contrôlée. Annals of the Association of American Geographers, 94(4), 848-867. https://doi. org/10.1111/j.1467-8306.2004.00438.x

Grasseni, C. (2017). The heritage arena: Reinventing cheese in the Italian Alps. Berghahn.

Gupta, A., \& Ferguson, J. (1992). Beyond 'culture': Space, identity, and the politics of difference. Cultural Anthropology, 7(1), 6-23. https://doi.org/10.1525/can.1992.7.1.02a00020

Gupta, A., \& Ferguson, J. (1997). Culture, power, place: Ethnography at the end of an era. In A. Gupta \& J. Ferguson (Eds.), Culture, power, place: Explorations in critical anthropology (pp. 1-29). Duke University Press.

Guy, K. (2003). When Champagne became French: Wine and the making of a national identity. The Johns Hopkins University Press.

Guy, K. M. (2011). Silence and savoir-faire in the marketing of products of the terroir. Modern and Contemporary France, 19(4), 459-475. https://doi.org/10.1080/09639489.2011.610165

Gyimóthy, S. (2017). The reinvention of terroir in Danish food place promotion. European Planning Studies, 25(7), 1200-1216. https://doi.org/10.1080/09654313.2017.1281229 
Handler, R., \& Linnekin, J. (1984). Tradition, genuine or spurious. The Journal of American Folklore, 97(385), 273-290. https://doi.org/10.2307/540610

Harbutt, J. (2003). The world encyclopedia of cheese. Anness Publishing Limited.

Harbutt, J. (2009). World cheese book. Dorling Kindersley.

Josling, T. (2006). The war on terroir: Geographical indications as a transatlantic trade conflict. Journal of Agricultural Economics, 57(3), 337-363. https://doi.org/10.1111/j.1477-9552.2006.00075.x

Kindstedt, P. S. (2012). Cheese and culture. Chelsea Green Publishing.

korycin.pl. (n.d.). korycin.pl. Retrieved July 17, 2016, from http://www.korycin.pl/index.php?action= dokument\&id $=48$

Low, S. M. (2009). Towards an anthropological theory of space and place. Semiotica, 175(1/4), 21-37. https://doi.org/10.1515/semi.2009.041

Maine, H. S. (1986 [1861]). Ancient law. University of Arizona Press.

Marcellino, R. M. (2003). Biodiversity of geotrichum candidum strains isolated from traditional French cheese. Doctoral Thesis, University of Connecticut. UMI.

Massey, D. (1999). Imagining globalization: Power geometries of time-space. In A. Brah, M. J. Hickman, \& M. M. Ghaill (Eds.), Global futures: Migration, environment and globalization (pp. 27-44). St. Martin's Press.

Matthews, M. A. (2016). Terroir and other myths of winegrowing. University of California Press.

Michałek, J. (2007). A catalogue of Wallachian and mountain cheeses. Wallachian Heritage in the Carpathians. Istebna: n.p.

Mijačević, Z., \& Bulajić, S. (2004). Traditional manufacturing of hard cheese - Kachkaval on Stara Planina Mountain. Acta Agriculturae Slovenica, 84(1), 11-15. http://www.dlib.si/details/URN:NBN:SI: doc-AWD90RQX.

Millet, M. (2019). From Ossau and Iraty to PDO Ossau-Iraty: The long-term construction of a product based on two distinct places. British Food Journal, 121(12), 3062-3075. https://doi.org/10.1108/ BFJ-10-2018-0719

Moore, A. S. (2003). Making cheese is her calling: Make that her second calling. The New York Times. December 21.

Moran, W. (1993). The wine appellation as territory in France and California. Annals of the Association of American Geographers, 83(4), 694-717. https://doi.org/10.1111/j.1467-8306.1993.tb01961.x

New South Wales Government. (2016). What is movable heritage and why is it important? Retrieved June 2020, from NSW Department of Planning, Industry and Environment: https://www.envir onment.nsw.gov.au/Heritage/aboutheritage/movableheritage.htm.

Nowak, Z. (2012). Against terroir. Petits Propos Culinaires(96), p. 108.

Parker, T. (2015). Tasting French terroir: The history of an idea. University of California Press.

Paxson, H. (2010a). Locating value in artisan cheese: Reverse engineering terroir for new-world landscapes. American Anthropologist, 112(3), 444-457. https://doi.org/10.1111/j.1548-1433.2010. 01251.x

Paxson, H. (2010b). Placing the taste of Vermont cheese. Cuizine: The Journal of Canadian Food Cultures, 2(2). https://doi.org/10.7202/044349ar.

Petridou, E. (2012). What's in a place name?: Branding and labeling cheese in Greece. Food, Culture and Society, 15(1), 29-34. https://doi.org/10.2752/175174412X13190510221869

Raxhimi, A. (2016a). Cheesy tale begins in Europe's majijuana capital. Balkin Insight. February 26, p. 4.

Raxhimi, A. (2016b). What we call Kashkaval is just a mess. Balkan Insight. March 4.

Raxhimi, A. (2016c). The historical roots of Kashkaval. Balkan Insight. March 14.

Robb, G. (2007). The discovery of France. Picador.

Rowlands, M. (2004). Cultural rights and wrongs: Uses of the concept of property. In K. Verdery \& C. Humphrey (Eds.), Property in question: Value transformation in the global economy (pp. 207-225). Berg.

Sarmiento, E. R. (2017). Synergies in alternative food network research: Embodiment, diverse economies, and more-than-human food geographies. Agriculture and Human Values, 34, 485-497. https:// doi.org/10.1007/s10460-016-9753-9

Simon, A. L. (1956). Cheeses of the world. Faber and Faber.

Strzemien, A. (2009). Italian city Lucca bans foreign foods to protect its cuisine. Retrieved July 2020, from Huffington Post: huffingtonpost.co.uk. March 27.

Swan, S. (2004). The treasury of Turkish cheeses. Boyut Yayin Grubu.

Tan, A. Ö. (2016). Turkey. In C. Donnelly (Ed.), The Oxford companion to cheese (pp. 732-734). Oxford University Press. 
Teil, G. (2012). No such thing as terrior?: Objectivities and the regimes of existence of objects. Science, Technology, and Human Values, 37(5), 478-505. https://doi.org/10.1177/0162243911423843

Tomasik, T. J. (2001). Certeau a la carte-translating discursive terroir in the practice of everyday life: Living and cooking. The South Atlantic Quarterly, 100(2), 519-542. https://doi.org/10.1215/00382 876-100-2-519

Trubek, A. (2008). The taste of place: A cultural journey into terroir. University of California Press.

Trubek, A. B., \& Bowen, S. (2008). Creating the taste of place in the United States: Can we learn from the French? GeoJournal, 73, 23-30. https://doi.org/10.1007/s10708-008-9175-3

Trubek, A., Guy, K. M., \& Bowen, S. (2010). Terroir: A French conversation with a transnational future. Contemporary French and Francophone Studies, 14(2), 139-148. https://doi.org/10.1080/17409 291003644206

Tsing, A. (2012). Unruly edges: Mushrooms as companion species. Environmental Humanities, 1(1), 141-154. https://doi.org/10.1215/22011919-3610012

Valsana. (2019). Where was Caciocavallo cheese first produced: By sifting through the myths and legends, we discovered a cheese that "straddles" two civilizations. Retrieved May 22, 2020, from https://www.valsana.it/en/blog/caciocavallo-cheese-origin/. March 18.

Weber, E. (1976). Peasants into Frenchmen: The modernization of rural France, 1870-1914. Stanford University Press.

West, H. G. (2013a). Appellations and indications of origin, terroir, and the social construction and contestation of place-named foods. In A. Murcott, W. Belasco, \& P. Jackson (Eds.), The handbook of food research (pp. 209-228). Bloomsbury.

West, H. G. (2013b). Thinking like a cheese: Towards an ecological understanding of the reproduction of knowledge in contemporary artisan cheesemaking. In R. Ellen, S. J. Lycett, \& S. E. Johns (Eds.), Understanding cultural transmission in anthropology: A critical synthesis (pp. 320-345). Berghahn Books.

West, H. G. (2014). Bringing it all back home: Reconnecting the country and the city through heritage food tourism in the French Auvergne. In N. Domingos, J. M. Sobral, \& H. G. West (Eds.), Food between the country and the city: Ethnographies of a changing global foodscape (pp. 73-88). Bloomsbury.

West, H. G. (2019). Savoring decay: Cheese, heritage and the allure of imminent dissolution. Gastronomica: The Journal of Critical Food Studies, 19(3), 47-59. https://doi.org/10.1525/gfc.2019.19.3.47

West, H. G. (2020). Crafting innovation: Continuity and change in the 'living traditions' of contemporary artisan cheesemakers. Food and Foodways, 28(2), 91-116. https://doi.org/10.1080/07409710.2020. 1745456.

West, H. G., \& Domingos, N. (2012). Gourmandizing poverty food: The Serpa cheese slow food presidium. Journal of Agrarian Change, 12(1), 120-143. https://doi.org/10.1111/j.1471-0366.2011. 00335.x

Whatmore, S. (2006). Materialist returns: Practising cultural geography in and for a more-than-human world. Cultural Geographies, 13(4), 600-609. https://doi.org/10.1191/1474474006cgj377oa

Whited, T. L. (2018). Terroir transformed: Cheese and pastoralism in the western French Pyrenees. Environmental History, 23, 824-846. https://doi.org/10.1093/envhis/emy057

Wilmsen, E. N. (1989). Land filled with flies: A political economy of the Kalahari. University of Chicago Press.

Wilson, J. E. (1998). Terroir: The role of geology, climate, and culture in the making of French wines. University of California Press.

Wolf, E. R. (1982). Europe and the people without history. University of California Press.

Publisher's note Springer Nature remains neutral with regard to jurisdictional claims in published maps and institutional affiliations. 